\title{
Governance Crisis and the Transformation of East Asian Capitalism
}

\author{
HYUK-RAE KIM \\ Graduate Schost of Internatimad Sindies. Yomser Liniversit?
}

In 1997, the Astaneconomit crisis, initially spatned in Thaikand debilitated

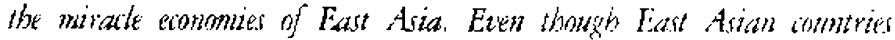

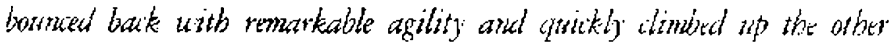
side of their $V$-shaped econmic grouth cunce. their resilience $i j$ jet to

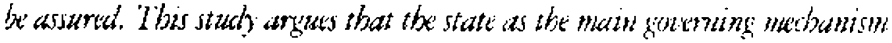

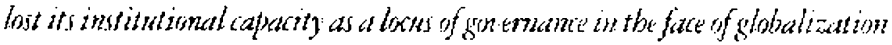

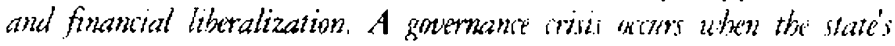
monitoring and disciplinary capacities beome usak and its credible: smmitment to ensure a secure economic detelopment becomes sererty challensed. Ulimutidy,

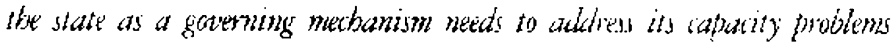

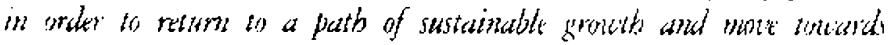

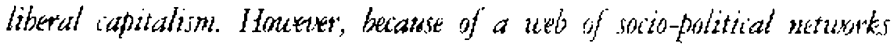
and contingent bistorical experiences, the extent is which the Fant Astan madel of capitalism uill tratsform into ibe Westim model of liberd capitalim is limited.

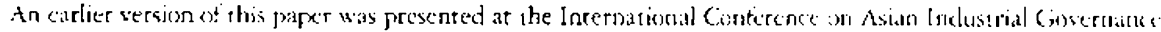
it Ewha Womans Unwersity on May 14́-15. 1999. This rescarcis wabs supposted by che Asia Rescirch Func: in 16)s.

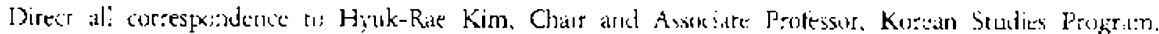

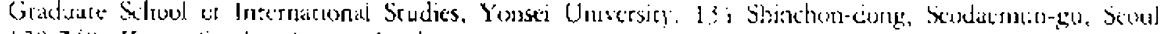

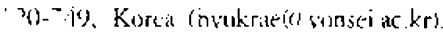




\section{INTRODUCIION}

7 he economic crisis, initially spawned in Thailand in 1997 , spread to ncightoring 1 countries of Southeast Asia and eventualy triggered serious turmoil for the miracle economies of Fast Asia. Even the resilient economics of Singapore, Taiwan and Hong Kong showed related problems, slowly being croded by the persistent weaknesses of their neighboring Asian economies. Thus, economic growth in the so-called four East Asian tigers hit its lowest level since World War 11 at negative 1.4 percent in 1998. However, after a perood of unprecedented economic tumoil, a lew encouragring signs of recovery slowly emerged in Asia. The Asian Development Bank recently anorounced that alxe Asian economic growth rate will rise to an average of 6.9 perceat this year, compared with 6.1 percent in 1999 (Financial Times, September 19, 20000).

Asian countries bounced back with remarkahle agility and quickly climlxed up the other side of their V-shaped economic growth curve. But, perhapss the optimistic v-shaped recovery of the prast two years was a bit premature. The beginning of new economic troubles has cmerged across the region, notably in lhailand, Indonesia, and to a lesser degrec in the Philippines. Among the three tast Asian countrics, Suuth Korea is not expected to have a severe reccssion, much like the one it experienced after the 199? financial crisis, but an conomic slowdown. The Japanesc economy appears to be improving, but it is still tar $t(x)$ early 10 assure that there is a strong recovery under way. Taiwan shows clear signs of an economic downturn, including a downturn in the senticonductor business cycle, depressing currency, and rising non-performing loans.

The signs of recovery were precarious from the start beciuse they were based on expectations resulting from the government's macroeconomic expansionary policies and stimulation measures. East Asian countries such as Korea and Japan have not yet made much progress towards addressing both inherent and structural tlaws that gave risc to the crisis in the first place. Taiwan inirially escaped the worst aspects of the regionicl crisis, but faces new challenges due to the minority government and its limited capacity in governing the national economy. Furthermote, the three coonomies are still contingent on such external factors as the sustainability of the ungoing heom in the U. S. econony, the prospect of the European Union economy, the stability of oil prices, and the vulnerability of South American economies to external shocks. The timing and strength of the recovery certainly depend to some extent un developments in the Asia region as a whole as well as on global and structural economic conditions.

There have been numerous debates over the East Asian model of capitalism, als a quest to find reasons for the conomic crisis and ways to return to a sustainable groweth path (Chang et al. 19y)8: Haggard 2000; Jomo 1998: H. Kim et al. 2000; Mathews 1998; Pempel et al. 1999). The most contentious deluate is on the root cause of the crisis. Some point to the institutional weaknesses of the so-called crony capitalism as a root cause. The institutional weaknesses inchide the collusive scate-business alliancte, an opaque and poorly regulated financial system. govermmentecontrolled nuedianisms for the allocation of capital, and non-transpatent corporate gowetnancs. Others atgale 
that market failures in over-licjudiated and under-regulater sinancial markets resulted in an over-retiance on short-term foreign capital and speculative investments. This view emphasizes that the devastating force of international (appital led $\omega$ a series of conomic crises in last Astil.

In searching for the cause of the crisis, this study attempts to addecss the following questions in relation to the future of Ease Asian capitalism. How vulnerable is the model of East Asian capitalism to external shocks? How resilient is the East Asian moxtel as an economic governance system.' W/ill the East Asian mextel of capitalism be transformed inco the Western nodel of liberal capitalism? And firally, what role will the state play in the transformation of the East Asian model of captalism:

This study atcompis to antower these questions by suggesting that the statc als the main governing nuechanism lest its institutional capacity as a lexus of econonde governance in the face of glohalization and financial liberalization $(\mathrm{H}$. Kim $200(0 \mathrm{~h})$. Furthernore, this study suggests that the diversity of capitalism will remain in the East Asian region although elements of liberal capitalism are evident in the reforming proxess. This is because inertia of historical and institutional contingencies over time in East Asia will nut be changed in a short period of time even during the period of conomic turmoil. This study finally argues that the state needs to have salience and should remain an importan actor even in the structural reform of ecomonix gowernance in Eist Asia.

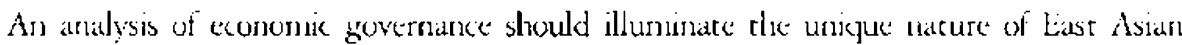
capicalism and assist wis in unelerstanding the origins of the economic crisis in this region.

\section{EAS'I ASIAN ECONOMIC CRISES}

In lace 1997, the Korean economy suffered a curtency crisis that was in part instigated by the broader Asian financial crises. However, well lefore the crisis, South Kurca had various fundanental tlaws in the national exonony: debt findncing and cross-sharctuoldings by majur cunglomerates, non-performing loans by funancial insticutions, and highly ley eraged business groups and financial instirutions ( $\mathrm{H}$. Kim zoo(k). Wore importantly, financial libcralization and the movement of massive capital across national borcless had shifted the South Korean governmenc out of its dominane position as che center point of economic governance.

Consequently, the 1997 crisis in South Korea brought an end to the prosperous era of $\$ 10,00(0)$ per capita income, as the nation's per capita GNP dedined to 9.8 percent that year. More significantly, the nation's econonic growth rate shrank from 5.0 percent in 15y) to negatrive 6. $:$ pereent in 1998 . The untemployment rate. which hate fallen

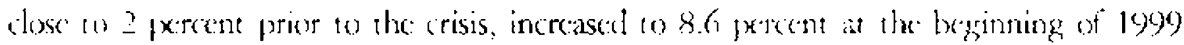
and dropeced to 3.4 percent in $20(x) . .^{1}$ In view of these apparent conomic troubles,

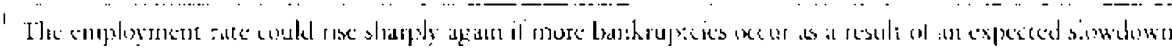

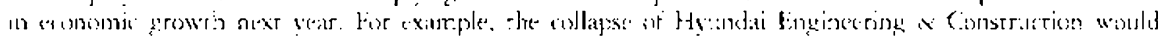

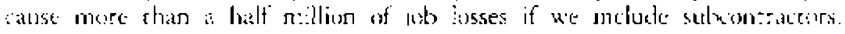


the Korean government can no longer avoid a comprehensive retorm program in the financial sector, the corporate sector, and the public sector. After inplementing reform programs, introduced in 1998 when Dae-jung Kirn came to power, South Korea bxunced back on track showing a 10.7 percent growth rare in 1999. But the Kurean economy is already showing signs of slowing down, after the crisp v-shaped recovery of the past two years.

Japan maincained an average GDP growth rate of 9.7 percent between 1956 and 1973, and 4.1 percent between 1975 and 1991 even after the oil crisis (Katz 1948). But Japan's economy has shown trouble ever since the inflated "bubble" prices cumbled in the legiming of the 1990s. Since the collapse of the 1980 s "bubble" in asset prices, economic growth in Japan slumped to 1 percent or less a year during the period of lok) and has not yet created an economic structure adjustable to the rapidly clanging modern economy in a competitive global market. Because of the lingering effect of asset price deflation, Japan is grappling with a banking crisis that has threatened to overwhelm the financial system and undermine its powerful industrial basc. Furthermore, the corporace secror is still facing serious challenges to overcome the excess capacity and debt created during the 1980 's "bubble". Because of the cconomic recession in Japan, uncmployment was at a post-war record level of almost 5.0 percent and monthly corporate bankruptcies were at an all-time high in 1998. With both increasing unemploynent and corporate bankruptcies, Japan expericned two consecutive years of negative growth not seco in two decades.

The Japanese government thus attempted to implement various scructural reforms to statilize the economy and financial markets, mainly through fiscal spending. For this, Japan has allocared massive stimulus packages wortl 117 trillion yen since 1992. The government was set to use a supplementary spending parkage worth some 4 arillion yon this year. With these reforms, Japan's cconomy was assumed to reach a critical curning point in 1999. The Economic Planning Agency in Japan released the grow'th rate for the fiscal year of 1999 to March 2000 which had risen to 1.4 percent (Financial Times, November 25/6, 2000). But there is little sign of higher growth yet. It is also not yet dear whether a recovery will be sustainable. One certainty is that Japan needs to consistently commit to the regulatory retom in order to return to a sustainable long-term growth path.

In contrist, Taiwan's conomy has escaped relatively unscathed and has performed well on most measures, even during the devastating carthquake that hit central Taiwan in 1999. Unilike Japan and South Korea, Taiwan's economy has been skillfully managed through a combination of tight exchange controls, low forcign debt, and conservative fiscal policies. Furthormore, the Taiwanese economy has continually adjusted itself to the production of higher value-added products produced by a large population of small-and medium-sized enterprises (H. Kim 1943).

Nonetheless, the laiwanese economy was affected by the Asian crisis. Taiwan's GIDP growth slowed to 4.7 percent in 1998 while Japan and Souch Korea recorded negative 
groweh. This growth may have been good by regional seandards, but it was the slowest recorded in 16 years. In addition, Taiwan's volume of exports decreased and showed its first negative growth in the last decade. Despite all of thesc crisis-related problems, the Taiwanesc economy has performed renarkably well on must measures. Thus it is expected to increase its GDP growth rate to the upper 6 percent this year. However, Tawan is now forced to atdress new challenges, including the trade slump, the shortage of experienced labxer in the electronics sector, sluggish rradicional industries, rising non-performing loans, and weaknesses in the financial sector.

\section{GOVERNANCE CRISIS AND 'THE TRANSFORMA'TION OF EAST ASIAN CAPITALISM}

Governance as a user-friendly "umbrella" coneepe (Frischtak 199.1) generally refers to how institutional relations in socjety are organized. In relation wo this paper. this term is being defined to refer to the capacity of governments to formulate and inplement sound policies in the management of a counery's economic resources and to credibly ensure a securc ensironment for economic transactions for develomment (Dhomte and Kapur 1996; Frischrak 1994; Frischrak and Atiyas 1996; Kautfrann ct al., 1999; H. Kim 2000b,c; Kooiman et al. 1993; Williamson 1996; World Bank, 1992. 1). Although similarities among the three Last Asian countries - Suuth Korta, Taiwan, and Japan might suggest a convergence toward a uniform East Asian capitalism, the threc countries have actually shown different trajectories of development $(\mathbf{H}$. Kin 1993, 1994). There have becre considerable vartations in the form of economic governance of the national conony: namely, chateril capitalism in South Korea (Anesden 1989); E. Kin 1997; H. Kim 1998, 2000a), lamily capitalism in Taiwan (Ciscenhalgh 1988; Redding 1990); Wong 1985), and alliance capitalism in Japan (Fruin 1994; Gorlach 19y2).

This paper will argue that divergence in the governance mode of the national coconony is constituced and shaped by the embodiment of state capacity (H1. Kin 199:1, 2000)b). This stucly will also arguce that the economic crisis stems from the state's inability to adequately and successfully fulfill its capacity in response to the rapidly changing onvironment of globalization and financial liberalization. State capacity basicilly refers to the ability of the stale and its burealuracy, through a centralized chain of command, to formolate and implement conomic policies and enforce monicory and disciplinary actions on economic actors and activities. State capacity could also bxe entanced to indude governance over the activitics of the private sector in an econsmy, derived from the insricutional link between the state and the private sector. The institutional linkage between the statc and the private sector can be underscoud as a form of economic governance through which buth siktes interact to address the market failures in various forms (Hollingsworth and Lindluerer 1994: H. Kin 2000(3). 


\section{Korenn Fonnomic Goternance in Transition}

In each alecade since 1960, South Korea has rripled the size of its cconomy. South Korea successfully developed a distiuctive ecomonic governance structure during its period of ecomemsic growth.' The concentration of state buseancratic pewer, ahe dominant position of the state in relation to the private seter, and its relative aluronomy from sxietal pressures helped to explain the dirigist approach to industrial transformation (1. Kim 1994). During the period of econumic growth, the South Kutean government extensively employed a wide range of tactics to ensure the prisate industry's compliance with its plans. Among them, the most widely usced stratesy wis the allociation of ceredit through the control of commercial and special banks (Cho 1997). Linder elese circum. stances, access to a stable and low-cost source of credit was considered coucial for the private sector throughout the high conomic growith px.rixd.

Hewever, by mid-199; various fundamental problens in the national coonemy; such as debe financing and cross-shareholdings by major business groups and the accumularion of non-performing loans by financial institutions, had surfaced. Under the umbrella of government proecetion, banks and other financial insticutions indulged in cuestionable lerding practices. while big businesses or dhatbol pursued excessively leveraged expansion. As is resule. South Korea faced austere measures prescribed by the IMF program in 1997. Also, dre sustanability of rapid economic groweth in South Korca has Lecen widely challenged by rising inflation, bankruptcies, uneroployment, and an unstable cursency.

The conomic governance constructed throughout the past several derades began to display its weaknesses. ${ }^{3}$ Korea's state capacity problems began when the state bureaucracy lost its centrality in maincaining a secure and consistent macro-economic cnvironment. While making efforts to overcome the difficulties that arose following its admission into the $\mathrm{OECD}$, the state failed to maintain its montoring and disciplinary tunctions as a locus of economic management in the face of timalcial liberalization (Lee and Kim

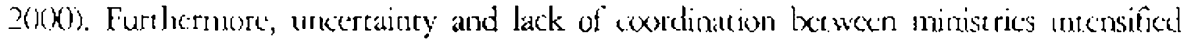
intri-bureaucratic conflices and led to inconsistercy and unpreblictability in governoment pxilicy, thus rhe state lost credibility in sustaining a secuse economic environoment. The advancement of political liberalization in the carly 1990s, as well as the deterioration of state capacity also coincided with growing weaknesses in state capaciry to coordinate the private sector in the policy-making process.

This is in part due co the expansion of the private sector. The private sector of thatsol, in rems of both size and power, eroded the ability of the statc a function in its past strums-armed fashion. The thatebl sector, in particular, succededed in transforming it hic rarchical relationship to a syrnbiotic one so that the articulation of hig business interests grew stronger (t. Kim 1997). As manifested in the frecplent (hanges in economic pollicies,

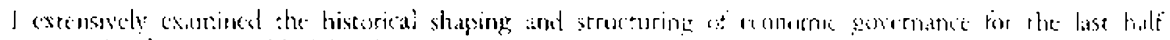

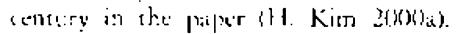

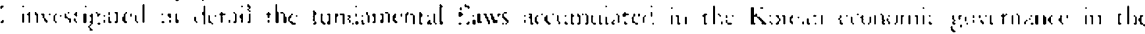
pajur [] 1 . Ki:1) 2(j)tk: 
the gresth-oriented policy network was transformed inco the rent-oriented policy netwerk in which the private sector heavily penetrated the formulation and implementation of conomic policies $(\mathrm{H}$. Kim $2000 \mathrm{~b})$. This becomes evident when the gorernment ardered (1) reduce their delotequity ratios from the reckless heights of 500 percene wo betow 200 percent. But dowhel found ways to resist by engaging (natsive share issues (a) lower their debt-equity ratio, while arhieving litele in cutring its total debt. In consecjuence, rhe dhethl sector incteased cross-shareholdings among group subsidiaries so that irs internal shareholding increased on average from 27.2 percent at the end of 1998 ti) 34.6 pactent in 1949 .

The immediate fear is that the country's industrial giants, including the Daew $(x)$ and Hyundai groups, are on the verge of collapse due to debt burdens exacerbated by the bailure of state-led reform. Ilice collapse of the Daewor) group', with record breaking debes of 80 trillion won, has planed further burdens on the finaluall markets. Banks also werry that weak batance sheets would make them the target of a state-led consolictation of the banking industry. In addition, the Hyundai group, with tot al dtbts of 5.2 trillion wen, may retrace the demise of the Daewo group. The government prefers not to deal with the unravelling of Hyundai Engineering \& Construction at the same time it faces [Jaewo Motor collapsing. The government bears that the hailure to reil over maturing corporate debt would trigger a new series of bankruptcies that would further weatern the timancial institucions. For this, the government is preparing 10 inject andether (i) trillion won in public moncy into weak financial institutions this yeat an top of more than 100 trillion won already spent.

The roxt of the economic turmoil in South Korea lies in the unicyle system of eronomic governance created throughout the past several decades $(\mathrm{H}$. Kim $2000 \mathrm{c})$. Signs that economic growth was regaining momentum became increasingly evident in 1999. This was party due to the strong efforts of the Korean gevernment to implement far-reaching macreconomic measures and structural reforms in the financial and cotporate sectors at well as in the labor market. However, resistance by the corporate and public sectors,

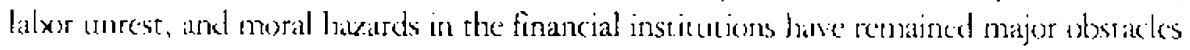
in the retorming process.

It is thus unclear wherher both the government and the corporate sectur will go far or tast enough in refurming Korean economic gowernance. Althougl major reforms

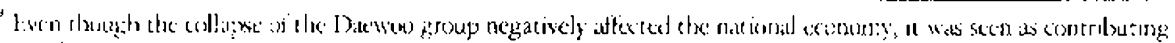

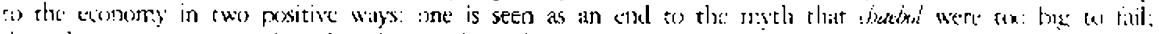

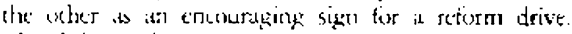

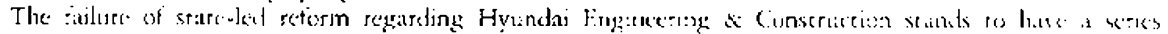

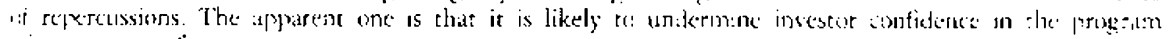
ilt (1)

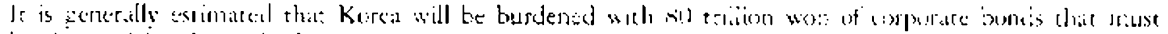

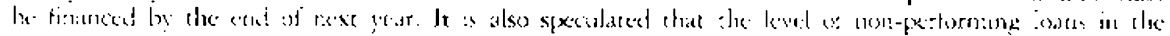

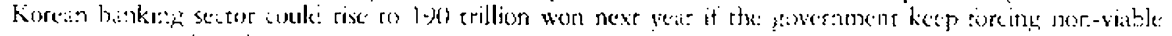

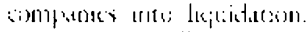

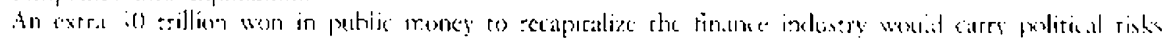

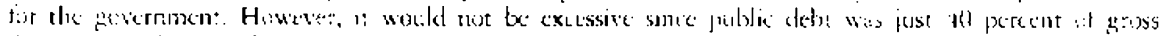

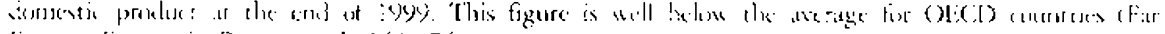

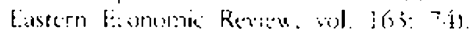


are gearing toward the implementation of the global standards of liberal capitalism such as transparency, the removal of moral hazard, and a regulatory regime rather than an interventionist one, the basic institutional scheme remains largely in tact. In the process of reformation, the government might simply adopt a stratcgy of fiscal spending and stimulus packages, similar to the strategy being used by Japan. Instead, the government needs ro deal with complacency engendered by the recovery, make a renewed push for corporate restructuring, and finally resrore confidence in the financial markets. In the process, the government should enhance its institutional capacity by escablishing a suitable and sound regulatory framework for comprehensive reform cfforts. If successfully accomplished, state capacity will be properly reshaped in a way to credibly ersure a secure environment for economic transactions in a market conomy without losing a locus of economic governance.

\section{Japanese Economic Governance in Transition}

Japan's economic growth bas been based on a model of governnent-regulaced capitalism. During this period, much emphasis was placed on the governing triad of interlocked private, potitical, and public insticutions - large industrial and financial enterprises, the Libetal Democratic Party (LDP), and the exonomic ministries which shared a common regard for the importance of aggregate ecomonic perormance (Karz 1998; Srokwin 1988). This exclusive coalition had the ability to arrive at a shared consensus about basic macromeconomic goals, and this Japanese bureacratic system of "administrative guidance" was a hallmark of Japan's political economy. Atrer several decades, however, che coherence and concentration of the bureaucracy in initiating and implementing a state development stracegy became increasingly diffused. Morcover, with increased economic power, the corporate sector became less dependent on the state bureaucracy in making its own investment decisions. In addition, political parties and other sectors of society began chipping away at the dominance of bureateracy over economic policy-making itself.

In particular, the institutional linkage between the state and rhe private sector, which was based on its structural interdependence through a stable long-term relacionship (1Dore 1986; Inai and Itami 1984; Okimoto 1989), exemplified the problem of structural rigidity in the face of globalization. State and business were informally bound together over a long period of time through interactive and consensual practices. In this policy network, business interests were both formally and informally integrated into burcaucratically sponsored negotiations by consultation and a consensus building process. Although this nerwork worked in a way to provide the private sector ad hoc or informal advice from minscries, ic became problematic particularly for international businesses larking the established bureaucratic relationships, and for domestic businesses preferring a less opaque system. In other words, both domestic and international businesses wanted to establish predictability through a clear regulatory framework as well as deregularion to enhance flexibility in a competitive global market. 
The Japanese bureaucracy was politically insulated from the legislature and other social torces, like those of South Korea and Taiwan. However, Japar differed from both South Korca and Taiwan in that cmphasis was given to the equal relationslip betwere the burcaucracy and special incerest groups (Johnson 1982; Wade 19)(). This produced institutional legitimacy for the creation of formal mechanisms of exchange between the government and soxial interest groups excluding labor $(\mathrm{H}$. Kim 19)4, 2000); Pempel and Tsunekawa 1979; Pempel et al. 1999). Formal inclusion of interest groups in both policy formation and implementation became a distinctive characteristic of the Japanese system. The government did not act until there was cnough agreement between the government and the concerned party. Ihe process of policy-naking on the basis of mutual consensus becane so complex that a great deal of time was lust building up consensus, which in turn resulted in ill-timed policy implementation and subsequent policy failures.

Although the Japanese government has successfully kept its economy from reaching the stage of complete collapse, its policy rools have appoared increasingly ineffective since the early 1990 s. Moreover, the state bureaucracy, which has effectively nun the country for five decades since 1955, is in growing disarray duc to recent failures in the expansionary macrocconomic management policy and successive cornuption scandals. Ihe I lashimoto, Obuchi, and Mori Cabinets undertwok the long-delayed fiscal and funancial reforms on non-performing loans by spending massive stimulus packages of 117 trillion yen since 1992. In particular, in the past two years, the government forced the financial institutions to deal with their mountain of bad loans by injecting a 70 trillion yen banking support package. As a result, the economy appears to be improving, but it is still unclear whether there is a strong recovery under way.

Considerable work remains to be done in order to make a sound transition in the tconomy. Bureaucratic mismanagement led many to believe that the state burcaucracy was incapable of responding quickly to the rapidly changing cconomic environment of globalization and financial liberalization. Since the bureaucrats lost the initiative in managing economic problems, responsibility was left to the politicians to devise policies. It was the LDP that presided over the "bubble" economy and led Japran into a recession. Motivated by electoral concerns, the LDP has fallen back on the traditional and conservative policy responses of bank bail-out programs and spending packages. The LDP was firmly enmeshed in a web of financial and political constituency of farmers, small retailers, and construction companies that were advetsely affected by libaralizacion of their markets in the reform process. Although the LDP has produced reforms recently, these have usually arrived in response to a demand from traticional vesred interests and were mostly hased on high fiscal spending.

After many delays and false starts, Japan's plans for restruccuring its economir system seen to be getcing under way. Real progress in financial reforms and corporate restructuring, combined with a further loosening of fiscal policy, pur Japan back onto a growth path. ${ }^{*}$ However, there are growing concerns over fiscal spending and its related debe problem, as well as over growing polarization across the economy. Debr to gross dontestic 
product is projected to be 130 percent by the end of this year." Also there is a growing concern about polarization across the economy: industrial production and corporate profits have been surging for large companies, while profies have been gloomy tor small ones.

To tackle these growing concerns, Japan needs to move towards a more flexible and market-driven economy by developing credible policies as well as an cifficient mode of implementation for the reform and liberalization of the financial secor. ${ }^{16}$ In addition, the factional politics in the IDP in favor of policy sratus quo, associated with slow reform and high fiscal sponding, should be eliminated to implement comprehensive structural reforms of deregulation and financial liberalization for a vibrant Japanese cconomy. In the process, the policy patterns of protectionism and patronage to reflect the interests of the party's key political constituencies need to be changed to adopt the global standards of liberal capitalism. Finally, the government should resort not to the burcaucratic system of administrative guidance, but to clear and transparent regulatory schemes for business. In gencral, the Japanese government needs to have salience as at locus of comonic gowernate in the reform process.

\section{Taiucanese Economic Covernance in Transition}

'The lawwanese economy has maintained high growth for the last few decades and inicially escaped the worst aspects of the regional crisis. This has been done through a less centralieed burcaucracy, with power over industrial policy issues dispersed among more ministries and agencies than those of South Korea or Japan (H. Kin 1994, 20006; Wade 1990 ). The state agencies have played mostly an advisory role in the policy process. While relying less on selective credit, the Tawanese government has relied more on arms-length fiscal and trade instruments as well as infraseructurc investments io steer private firms. 'The government has also used more state-owned enterprises to develop selected industries rather than create "national champions" of large privatc firms. Considering that state planning has usually been done in a loose, non-command style, there has been no rigorous enforcement of obligations via compulsion in statc planning (Hamilton and Biggart 1988; H. Kin 1994). The statc coonomic bureaucracy has less authoritatively and forcibly asserted substantial influence over the national cconomy, compared with the buscaucracies of Japan and South Korea.

Driven by an anti-big business capitalist stance and fear of the political potential of native lawwanese economic power, the government has devcloped a weak jolicy network

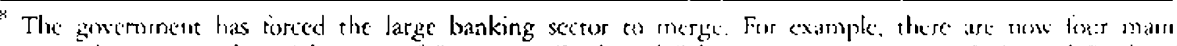
merged groups: a tinancial group of Sumitomo Bank ind Sikura gecup, a wroup of Industrial Bank of

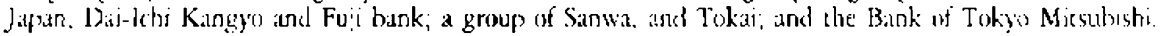

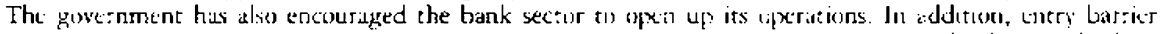

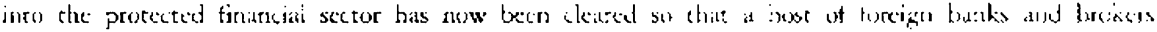
have purchased domestir rivals. incesasing rheir market share in Jiajoin

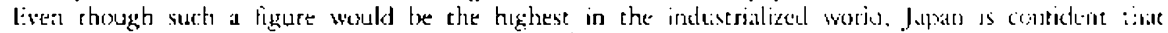

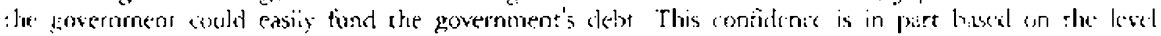
of assets that the government lockds.

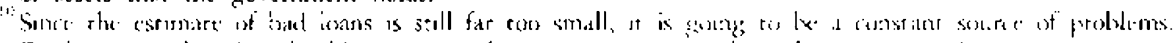
Fusthersose, the giant basking mergers have not get renored mude excess cilpacity
} 
(Cheng 19\%0: H. Kim 1994, 2000b; Wade 1990). The government has also discouraged the formation of large-scale organizations and the accumulation of coonomic power in private hands. Ihus, the state and the private sector trave remained apart. This lack of an extensive web of thannels to the private sector has constrained state officials in initiating and implementing a state development strategy. Within this thin policy network with the private sector, the government only gets information ablout the production capability of individual firms through such means as the export quality control scheme, the lisan guarantec scheme, and the external marketing agency (Wade 19\%). On the basis of this information, the government undertakes administrative guidance ower private investment decisions. State-private sector negotiations are, thus, event-based and take plate with individual firms rather than with aggregrations of forms.

Another feature distinet to Tawanese sociery is that the separation lxtween political power and wealth roughly parallels the ethnic cleavage berween the Mainlanders and the Taiwanese (H. Kin 1994, 200(0)). But this has dranatically changed after the March presidential election victory of Chen Shuj-bian and his Democratic Progressive party, resulting in the end of more than half a century of nule by the Nationalist party. The transfer of power hás in curn brought a new tension between Tajpei and Beijing as well as bxeween 'Tawanese and mainlanders. Furthermore, the minoricy government searching for Tawanese identicy and independence has ouch to contend within a hostile legislature, which in eurn forces the government wa pay more atention to dections which ate to be hedd late next year in 2001 .

In the tace of the current financial and economic crises of the Asian region, Taiwan has not yet developeit serious symptoms of the crisis. IThe resilience of the Taistanesc economy has been based on ats small and medium-scale busincsibs accounting for more this half of total prextuction (H. Kim 1993). Unlike the rigidly controlled and vertically

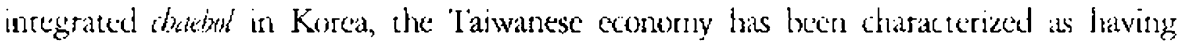
looscly coupled networks of small and medium-scale family businesses (Greenhalgh 1988; Wong 1985). Bue this form of family capitalism in Taiwan is fragile since it is quice sensitive to the frequently changing pattern of global demands. In addition, strategic industries bave been governed by the public sector, composed of mostly lijestream industries like energy, heavy machinery, shipbuilding, and stecl, which have prosen to tx the most inefficient sectors in the economy. The use of state-owned enterprises as an instrument to develop strategic industries became an impediment for further development of the Taiwanese economy. Once accounting for nore than half of the GNP, the state-ouned enterprises have accounted for just over 10 percent in recent years. Unless this sector is decentralized and state involvement in these private sector industries is reduced, there is the threat of a future crisis.

Furthermore, the Taiwanese econemy faces new challenges including a growing polarization across the economy and an emerging weikness in the financial secror. While the electronics sector is proving to be an engine of growth, the sluggish traditional industries are seen as al source of trouble. In addition to polarization, the dynamic electronics sector which accounts tor more than 30 percente of '[aiwanese exports, faces it slowing 
global demand for expors. a shurtage of skilled labot, and a narrowing profit margin. The traditional old economy has shown pour corporate governance and rising costs in a competitive market. In addition, the financial litxralization which began in the early 1990 s has eventually caused a series of problems. For example, average non-performing loans hit a record 5.36 percent of total commercial bank lending (Financial Times November 30, 2000). The regional banking sector, which is small in terns of cotal assets, has been porrly managed and overcrowded. Recent failures of a few regional small banks have cut down confidence in the marker.

Frictions between executives and lawmakers. as well as a lack of coordination within the framework of thin policy network, have had a chilling effece on investor cunfidence; witl the stexk market falling by 50 percent this year. Heavy reliance upon the export market and fluctuations in the regional economy are now creating unprecedetuted challenges. The minority government, together with the private sector, must inmediately deal with the new challenges including a downturn in the semi-conductor cycle, rising bad loans, depressing currency, and weaknesses in the financial sector. Since the minoricy government has yet to find a coherent voice on economic policy, it urgently needs to enlance its burcaucratic capacity to formulate and implement sound policie's. The government will also nect to address the issue of uncertainty and lack of coordination with the legislarurc in order to set a clear sense of priorities in the reform process and eventually to crsurc a secure and credible economic envirenment. In shore, sources of flexibility and dynamism in Tawanese economic governance need to b $x$ further evaluated in the face of the East Asian economic crisis.

\section{CONCLUSION}

The 1997 economic crisis in the region led to the belicf thar the state, as the main governing mechanism in the East Asian development model, lost its capacity as a locus of economic governance. Specifically, this study argues that the cconomic crisis exposed the problems of state capacity in the region of East Asia. These economies have experienced severe setbacks because of the weakening capacity of their states to credibly ensure a secure economic environment. The governance crisis of Last Asian capitalism tuok place because the state's monitoring and disciplinary capacities became w'tak and failed to actiust to the rapidly changing environment. In gencral, crisis ensues when the statcis cconomic policies lerome unpredictable and inconsistent due to intra-hureducratic: conflicts and mismanagement of proper regulatory systems, and when the state's coxordination with the private sector is transformed into a rent-oriented network where the private sector heavily influences economic policies (H. Kim 2000(b). In the face of crisis, Fast Asian states need to undertake real reform that recuires much more political will and a clear sense of priorities in order to enhance their institutional capacities of economic governance.

We must carefully examine the present economic conditions, their moxtes of governance, 
and their state capacitics to determine whether or not the East Asian moded of capitalism is coming to an end. Although major retorms shift toward global standards of litxral capitalism, the basic insritutional structure of the Fast Asian states remains largely in tact. In the process of reformation, the state as a governing mechanism needs to address its capacity problems in the wake of the conomic crisis and parhaps find a new path toward sustainable conomic growth. Specifically, the state needs to enhance its monitoring and disciplinary capacity as a locus of econonic governance, restore credibice comnitment in the proxess of policy implementation, and establish a system in which the state is not caprive to vested interests.

Ac the current stage, one may not be able to conclude whethes the East Asian form of capitalism will evolve into the Western model of liberal capicalism. As long as Confucian-authoritarian and familial values remain influential (11. Kim 199)8, 20(0)(x), the public demand for market democratization will remain unsolved and the diversity of capitalism will still remain (Lee and Kim 2000). What is certain is that the state needs to enhance its capacity as a locus of economic governance if it wants to successfully implement the structural economic reforms of liberal capitalism. Because of a web of socio-policical networks and contingent historical experience, the cxtent to which the Last Asian noxdel of capitalism will transform into the Western muded of liberal capialism is limited.

\section{REFERENCES}

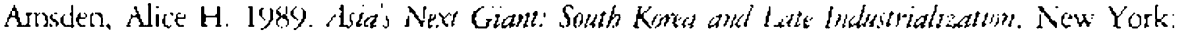
Oxtor! Unversity Press.

Chang, Ha-Joon, et al. 1998 . "Interpreting the Korean Crisis: Iinancial Liberalizarion, Industrial Policy and Corporate Covernance." Camividye' Joumul of Fanomic 22: 735-46.

Cheng Tun-Jen. 1990. "Political Regimes and Development Strategies: South Korea and Iawan." In Mantufuturing Mirale, eds. Gary Cereffi and Donald L. Wyman. Prinketon, N.J.: Princeron Coniversity Press.

Cho, Youn Ja. 1997. "Government Intervention, Rent Distribution, and Fconomic De-

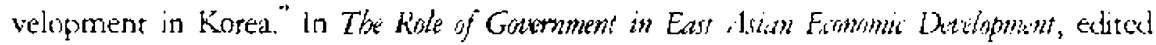
by M. Aokj et al. Oxford: Oxford University Press.

Dhonte, Pierre and Kapur, Ishan. 1996. "Toward a Markec Lomony: Structures of Governance." IMF Working Paper 97/11.

Dore, Ronald. 1986. Flexihte Rigidities: Industrial Polin and Simtural Adjustment in the Japanese' Exmom. 1970-1980). Stanford: Stanford University Press.

Far Eastern Economic Review, Vol 163.

Finarkial Tirnes. $20 \times 0)$. Novesnber 25, p.6.

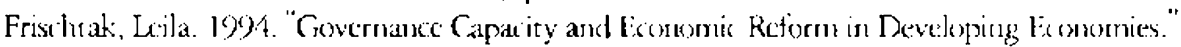
World Bank Technicai Paper No. 25\%.

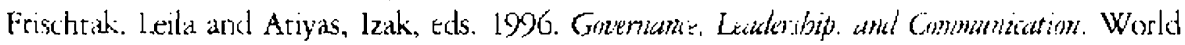
Bank.

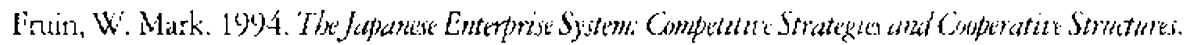


New York: Oxford Liviversity Press.

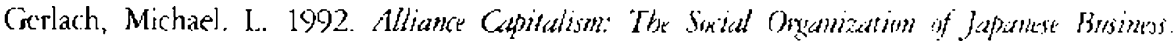
Berkeley: Univensity of Califurnia Press.

Greenhalgh, Susan. 1988. "Fanilies and Networks in Taiwaris Econumic Development." In

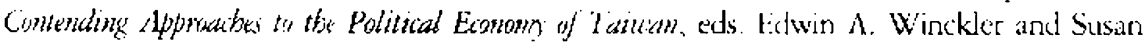
Grccrutuagh. Armonk, N.Y.: M.E. Sharpe.

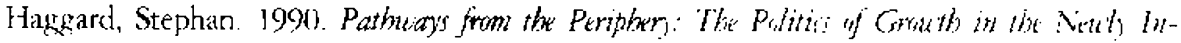
dictralizing Fionsmies. Ithaca: Cornell University Press.

Harrilton, Gary and N. W. Biggart. 1988. "Market. Culture and Authority: A Comprarative

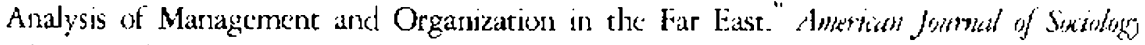
9.1: 552-94.

Hollingsworth, J. Roger and Leon lindberg. 1994. Gotrming Capitalist Finmomiks: Pentamuative and Contmol of Exnmmi Seitors. New York: Oxford University Press.

Imai, Ken-Ichi and H. Itami. 1984. "Interpenetration of Organication and Market." In fermational formal of Industrat Omganization 2: 285-310.

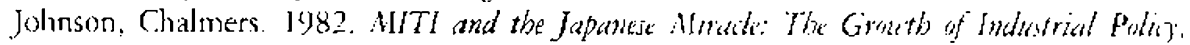
1925-19:5. Stantord: Stanford University Press.

Jomo, K. S. 1998. Tigens in 'Tnuble. Hong Kong: l long Kong Liviversity Press.

Katz, Richard. 1998. The System that Sourd: The Rise and Irall of the Japanese Ecommin Mirate. New York: M.E. Sharpe.

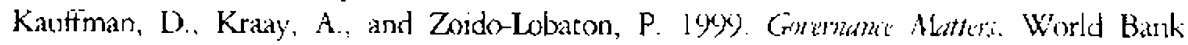
Working Paper. Washington D.C.: World Bank.

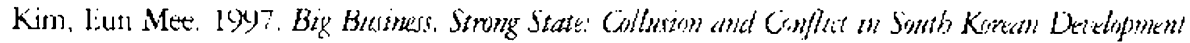
19(x)-19\%). Albany: Stare Liniversicy of New York Press.

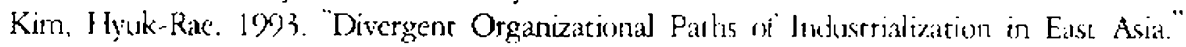
Astan Perspettite 17: 105-35.

1994. "Ihe State and Economic Organization in a Comparative Perspective: The Organizing Moxte of the East Asian Political Country." Kortan Sotzal Satent Jotmat 20: 91-120.

1998. "Family Capicalism and Corporatc Structure in South Korea." Korut Fräts 6. $55-67$.

.2(0)(0) "The Variability and Vulnerability of Korean liconomic Govennanec." Jommal of Comtempurar, Asia Vol. 30; 199-220.

. 20)(ob. "Fragility or Continuity?: Economic Cnwernance of East Asiarn Cayjutilism." In Polition and Marketi in the Watee of the Lrian Criri!, edited by Hyuk-Rac Kim ot al. london: Rourledge.

2000k. "Kurea's Economic Governance in Transition: Governance Crisis and the Future of Korean Capsatism." Kerea Obsener 31 (4): $553-77$.

Kim, Hyuk-Rae et al. 2000 . Politios and Markete in the Wake of the Asian Cring. Iondon: Routledge.

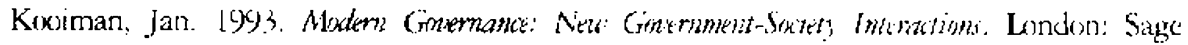
Pulvications.

Lee, Y. I and H. R Kim. 1999. "The Ditemma of I libralization: Financial Crisis and ine. Transformation of Capitalism in Sourn Kurca." In Prititio and Mwket in the Wake the Litan Critis, edited by Hyuk-Rae Kim et al. London: Routledge.

Mathews. John A. I (x) B. "Fashioning a New Korean Model but of the Crisis: The Rebuilding

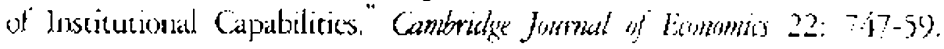




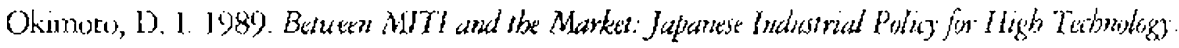
Stantorci, Calif: Stanford tiniversity Press.

Pempel, T. J.et al. 1999. The Politic of she Asian Crists. Ithaca, N.Y.: Cornell Univensity Press.

Pempxl, 'I. J. and K. 'I'sunekawa. 1979. "Corporatism withou Labor?" l'he Japranese Anomaly."

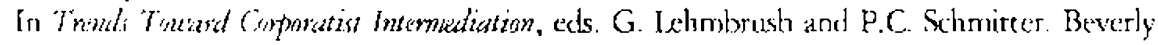
Hills: Saye.

Redding, S. (;. I9G). The Spint of Cbinese Capialismi. Berlin: de Ginyter.

Suckwin, J. A., ed. 1)88. Dyramic and Immbilist Apteats of Japanese Politics. London: Macmillan. Wade. Rober. 1990. Goterning the Harket: Eonmmic 'Theory and the Rols of Gonemmint in Fat Astam Industrializatiom. Princeton: Princcton Liniversity Press.

Williamson, Oliver. 1996. The Mechanisms of Governance. New York: Oxfori University Press. Wong, 5. L. 1985. "The Chinese Family Firm: A Model." British Jounut of Sentolog 36: $58-\div 2$

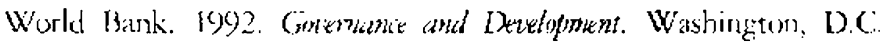

